\title{
The impact of economic incentives on population instability in rural settlements (case study: Khoosf county)
}

\section{El impacto de los incentivos económicos en la inestabilidad de la población en los asentamientos rurales (estudio de caso: condado de Khoosf)}

\author{
Mahdi Niyazi \\ Department of Geography and Rural Planning, Mashhad Branch, Islamic Azad University, \\ Mashhad, Iran \\ ORCID: https://orcid.org/0000-0002-6746-6863 \\ Hamid Jafari \\ Department of Geography, Mashhad Branch, Islamic Azad University, Mashhad, Iran \\ ORCID: https://orcid.org/0000-0002-2007-562X \\ Katayoun Alizadeh \\ Department of Geography, Mashhad Branch, Islamic Azad University, Mashhad, Iran \\ ORCID: https://orcid.org/0000-0001-7875-0977
}

Received 02-08-20 Revised 04-10-20

*Correspondence

Email: hamidjafari@yahoo.com
Accepted 01-11-21 On line 01-18-21

\section{Cite as:}

Niyazy, M., Jafari, H., \&Alizadeh, K.. (2021). The impact of economic incentives on population instability in rural settlements (case study: Khoosf county). Propósitos y Representaciones, 9 (SPE1), e888. Doi: http://dx.doi.org/10.20511/pyr2021.v9nSPE1.888 


\section{Summary}

Today, population instability is one of the most important problems in Iran's rural settlements despite of planning, spending money, and large investments. Since rural migration is for logical reasons, we should seek ways to slow down the process of migrating to cities or replacing rural migrants from central towns to small towns and central villages that have more facilities and services and prevented the consequences of migration that negatively impact the economic structures of cities and villages. The research is applied in terms of purpose and nature and is descriptive-analytical, in terms of methodology. The population consisted of 41 villages over 100 populations with 4226 households and 13892 populations which according to geographical distribution, population categorization and population decline during 2006 and 2016, 20\% of them (8 villages) with 796 households was selected as sample. A total of 259 questionnaires (based on Cochran formula) were distributed among the sample households based on simple random method. In this study, one sample t-test was used to analyze quantitative data and Friedman test was used to rank the effect of economic incentives on population instability. Based on the results of the present study, it can be concluded that economic factors (unemployment and low income) and lack of facilities and services have the most relationship with population instability in the Khoosf settlements.

Keywords: Economic incentives, Rural population instability, Khoosf city

\section{Resumen}

Hoy en día, la inestabilidad de la población es uno de los problemas más importantes en los asentamientos rurales de Irán a pesar de la planificación, el gasto y las grandes inversiones. Dado que la migración rural es por razones lógicas, debemos buscar formas de ralentizar el proceso de migración a las ciudades o reemplazar a los migrantes rurales de los pueblos centrales a pueblos pequeños y aldeas centrales que tienen más instalaciones y servicios y evitan las consecuencias de la migración que impactan negativamente en la población. estructuras económicas de ciudades y pueblos. La investigación se aplica en términos de propósito y naturaleza y es descriptivo-analítico, en términos de metodología. La población consistió en 41 aldeas sobre 100 poblaciones con 4226 hogares y 13892 poblaciones que de acuerdo a la distribución geográfica, categorización poblacional y declive poblacional durante 2006 y 2016, se seleccionó como muestra el $20 \%$ de ellos (8 aldeas) con 796 hogares. Se distribuyó un total de 259 cuestionarios (basados en la fórmula de Cochran) entre los hogares de la muestra según el método aleatorio simple. En este estudio, se utilizó la prueba t de una muestra para analizar los datos cuantitativos y la prueba de Friedman para clasificar el efecto de los incentivos económicos sobre la inestabilidad de la población. Con base en los resultados del presente estudio, se puede concluir que los factores económicos (desempleo y bajos ingresos) y la falta de instalaciones y servicios tienen la mayor relación con la inestabilidad de la población en los asentamientos Khoosf.

Palabras clave: incentivos económicos, inestabilidad de la población rural, ciudad de Khoosf 


\section{Introduction}

Rural-urban migration is a phenomenon that has appeared in the process of industrialization of countries and many social and spatial changes of societies are also due to it. It started in favor of industrial and service activities. Primary biological and economic foundations prevailing in all countries based on rural bio-agriculture and agricultural livelihood. Gradually, with the arrival of the waves of modernity and the transition from the Industrial Revolution, it gives way to urban life and industrial and service livelihood (Rostamalizadeh et al., 2013: 506). To ensure the stability of the settlement during spatio-temporal processes (Jangi, 2016: 24).

The economic, social and environmental aspects of rural areas are complex in nature and have profound implications for sustainability. Urban development policies over the past two centuries, due to rapid industrialization, due to economic, social and cultural differences, one It is one of the global problems of humanity that defines urban and rural civilization (Burja, 2014: 1861).

Benefiting rural communities from social capital and effective planning for its increasing promotion, by increasing the level of social awareness of villagers, social cohesion and trust in their community, developing social networks and improving their social participation in development activities, causes communities Rurally pursue and achieve their common goals more effectively and efficiently, and by diversifying the rural economy, participating in emergencies, optimally distributing resources and facilities, reducing production costs, increasing labor productivity and reducing unemployment, and protecting and restoring the village's natural resources play an important role. Sustainable development of rural areas. In fact, social capital as a cohesive factor, plays an important role in accelerating and facilitating the development of local network structures, which ultimately leads to rural development.

Economically, Bales Barrow sees immigration as an individual choice. According to him, people decide to emigrate when the expectations for economic benefits exceed the costs. According to this guideline, immigration may be considered as a mindset that one pursues in order to gain more benefits. Therefore, in this view, individual characteristics such as age, gender, material aspects, level of education and type of job can be effective in motivating migration. In this theory, migration is an individual matter and people who have the highest amount of economic capital migrate in order to stabilize their position (Ardhaei et al., 2017: 268).

Khoosf city was created in May 2012. According to the results of the census in 2016, the population of Khoosf city was 27599 people, of which 9306 people (33.7\%) live in urban areas (Khoosf, Mohammadiyeh) and 18294 people (66.3\%) live in rural areas. This indicates that the majority of the population in the area lives in villages. However, its trend has been decreasing during the 2006 to 2016 censuses, so that the rural population of the city has decreased by $10.86 \%$ compared to 2011 and by $21.1 \%$ compared to 2006. Also, the number of settlements with a population of Khoosf city, according to the census of 2016, was 196 points, while in 2006 this number was 272 points, which indicates the evacuation of 76 villages in the city.

The main purpose of this study is to investigate the effect of economic incentives on population instability in rural settlements (Case study: villages of Khosf city) and the hypothesis of this article is that it seems that between economic factors (unemployment 
and low income) and population instability There is a significant relationship in the studied rural settlements.

\section{Literature review}

Latifeh et al. (2016) investigated the economic factors affecting the instability of rural settlements (Case study: villages of Damavand city). The results showed that economic factors such as lack of facilities, employment, income and lack of public and private investment have affected the instability of villages in the region and has made the development process a serious challenge, therefore, economic empowerment of villages can Lead to the sustainability of rural settlements.

Ghasemi (2015) has studied the spatial instability of rural settlements in the cradle of Dalahou city. The results of this study show that among the factors such as limited water and soil resources, unemployment, low income and lack of services and facilities, etc. that have been effective in rural instability, according to research hypotheses, economic factors and government policies in the process of becoming unstable. Rural areas have played a key role. Among the economic factors, the factor of employment and income has definitely played a decisive role in the sustainability of rural areas, which warns of the need for the government's basic attention in planning and adopting favorable policies.

Tavakoli (2014) investigated the socio-economic sustainability of rural settlements in North and South Khaveh rural areas of Lorestan province. The results show that $92 \%$ of the studied villages are in semi-stable conditions with TOPSIS method and $96 \%$ with Morris method. There is a significant difference between the two methods in the $99 \%$ confidence level. There was no relationship between the level of stability of villages by TOPSIS method and population, but there is a positive and significant correlation between this variable and the population by Morris method.

Yeganeh et al. (2014) researched on diversifying the rural economy in order to achieve sustainable development. The results show that there is a significant relationship between economic diversity of villages and their sustainability at the level of $0.5 \%$ alpha, so that with increasing economic diversity at the level of the studied villages, the degree of sustainability of each village also increases.

Khadivi et al. (2012) in an article examined the economic structure of rural households and its effects on population instability of rural settlements (Case study: Sarayan city). The collected data were analyzed using correlation coefficient and ANOVA statistical tests. The test results showed that the average per capita income from economic activities has a significant difference between the main occupations. Also, there is a significant relationship between agricultural structure and per capita household income resulting from this sector, and also a significant relationship between per capita household income and job migration was confirmed.

Mechaniki et al. (2011) Investigated the social relations between urban and rural areas and population instability of rural settlements; a case study: the central part of Birjand. The results show that there is a direct relationship between population flows in the study area with population evacuation on the one hand and the instability of rural settlements on the other hand, which is due to the social relations between urban and rural areas. 
Javan et al. (2011) studied the demographic stabilization of rural settlements in Mashhad, emphasizing the approach of diversification of economic activities. The results obtained from three hundred and eighty households and forty-one settlements show that the existence of "diversity in economic activities" in rural settlements of Mashhad has a positive effect on "population sustainability", which is mainly due to the diversity of activities. The economy is non-agricultural. In fact, diversity in the activities of the agricultural sector does not have much effect on the population stability of rural settlements in Mashhad, which is due to the phenomenon of drought and low income.

$\mathrm{Lu}$, Zheng and Wang (2017) studied migration and popular resistance in rural China: Wakan and its suburbs. Findings indicate that the role of returned migrants who act as a means of transmitting information and ideology directly leads to rural resistance in the communities of origin.

Semenova, Genadievna Busalova, Eremina (2016) surveyed the assessment of sustainable development of rural areas of Russia. The results of this paper show that the proposed "polygonal" method for integrated assessment of sustainable development of rural areas makes it possible not only for itself at the general level but also for assessing sustainability in a specific context (economic, social, environmental). It allows the assessment of factors affecting the development of sustainability in rural areas. And the result of this assessment in rural areas of Russia is that due to the high growth of economic indicators, special attention should be paid to environmental problems and issues related to improving the quality of life of villagers.

\section{Methodology}

In the 2016 census, 41 villages had a population of more than 100 people, $20 \%$ of whom were selected as a sample. In selecting the sample villages, geographical distribution, population classification and population reduction during the period 2006-2016 have been considered, and finally 8 villages were selected as the sample. Then, according to the total number of households in these villages (796 households), 259 questionnaires were distributed in these villages based on Cochran's formula (Table 1).

Table 1

\section{Spatial distribution of the questionnaire}

\begin{tabular}{|l|l|l|l|}
\hline No. & $\begin{array}{l}\text { Name of the } \\
\text { village }\end{array}$ & Number of households & $\begin{array}{l}\text { Number of questionnaires } \\
\text { in proportion to the number } \\
\text { of households }\end{array}$ \\
\hline 1 & SarvAbad & 94 & 31 \\
\hline 2 & Ark & 45 & 15 \\
\hline 3 & Binabad & 48 & 15 \\
\hline 4 & Hamand & 55 & 18 \\
\hline 5 & SalmAbad & 54 & 17 \\
\hline
\end{tabular}




\begin{tabular}{|l|l|l|l|}
\hline 6 & AkbarAbad & 88 & 29 \\
\hline 7 & TaghiAbad & 72 & 23 \\
\hline 8 & GhalehZari & 340 & 111 \\
\hline \multicolumn{2}{|l|}{ Sample community size } & 796 & 259 \\
\hline
\end{tabular}

In this study, the most appropriate tool was a questionnaire. In this study, Cronbach's alpha method was used to measure reliability, which is used in most scientific researches. In the pilot sample, Cronbach's alpha coefficient for questionnaire variables was measured as shown in Table 2.

Table 2

Cronbach's alpha coefficient of the questionnaire

\begin{tabular}{|l|l|}
\hline Variables & Cronbach's alpha coefficients \\
\hline Lack of facilities and services & 0.882 \\
\hline Unemployment and low income & 0.919 \\
\hline
\end{tabular}

Due to the fact that Cronbach's alpha coefficient is more than 0.7 , the reliability of both desirable evaluation and internal validity is confirmed. The present study used Delphi technique to assess the validity of the questionnaire. In this way, the researcher-made questionnaire, after reviewing and correcting the issues raised by the professors, was finally approved by the supervisors and advisors, and the questionnaire was finalized in the form of 22 questions based on the Likert scale. In this research, descriptive statistical methods (frequency, frequency percentage and average) are used to analyze the data. In inferential statistics, a one-sample t-test was used to examine the status of variables and the effect of each variable on population instability in rural settlements.

In order to rank each of the factors (lack of facilities and services, drought and economic factors (unemployment and low income), Friedman ranking test is used. The software used in this study for data analysis is SPSS software.

\section{Findings}

Khoosf city is located in the southwest of South Khorasan province and in the range of 57 degrees and 57 minutes to 59 degrees and 22 minutes' east longitude and 31 degrees and 20 minutes to 33 degrees and 13 minutes' north latitude (Statistical Yearbook of South Khorasan Province, 2016: 62). This city is limited to Sarayan and Birjand cities from the north, Nehbandan city from the southeast, Kerman province from the south, Sarbisheh city from the east and Tabas city from the southwest (Rasti, Ashrafi, 2016: 47). 
Khoosf city with an area of 16029 kilometers square, which is equivalent to 10.6 percent of the area of South Khorasan province. It now has 2 districts and 5 villages. According to the 2016 census, the population of Khoosf city is 27,600 people with 7942 households, of which 9307 people live in urban areas and 18293 people live in villages and hamlets of the city.

\section{Table 3}

Political divisions and size of Khoosf city in $\mathbf{2 0 1 6}$

\begin{tabular}{|l|l|l|l|l|l|l|}
\hline City & Section & $\begin{array}{l}\text { Name of } \\
\text { the village }\end{array}$ & $\begin{array}{l}\text { Rural } \\
\text { Center }\end{array}$ & $\begin{array}{l}\text { Date of } \\
\text { Establishment }\end{array}$ & $\begin{array}{l}\text { Area } \\
\left(\mathrm{km}^{2}\right)\end{array}$ & $\begin{array}{l}\text { Rural } \\
\text { population } \\
2016\end{array}$ \\
\hline \multirow{3}{*}{ Khoosf } & Markazi & Khoosf & Khoosf & 1987 & 5072 & 6466 \\
\cline { 3 - 7 } & $\begin{array}{l}\text { Kajan } \\
\text { Plain }\end{array}$ & $\begin{array}{l}\text { Majan } \\
\text { Plain }\end{array}$ & Khor & 2012 & 1122 & 2476 \\
\cline { 2 - 7 } & Barakouh & Gol & 1987 & 736 & 3520 \\
\cline { 3 - 7 } & GhalehZari & AliAbad & 1990 & 8365 & 3425 \\
\hline
\end{tabular}

Source: Management and Planning Organization of South Khorasan Province, Deputy of Statistics and Information

Khoosf city naturally includes three parts: mountain plains (Khoosf village), eastern foothills (Barakuh and Majan plain villages) and dry deserts in the western half (GhalehZari village) (Nikzad, Sedighiyan, 2015: 2).

Khoosf has a relatively high altitude from the surface of the high seas so that the height of most of its points is not less than 800 to 900 meters. The high part of Khoosf is not very high compared to altitudes such as Alborz and Zagros, so that no point of it even reaches 3000 meters. In Khoosf city, highlands and mountain ranges are located in the northern and northeastern parts.

The income and employment status of the sample villages through animal husbandry is shown in Table 5. According to the information in the table, the highest income for households belongs to camel breeding and the lowest income belongs to heavy livestock. Also, the highest employment rate is related to light livestock (sheep) and the lowest employment rate is related to heavy livestock (cattle and calves).

\section{Table 4}

\section{Income and employment resulting from livestock breeding in sample villages during the 2017-2018 crop year}

\begin{tabular}{|c|c|c|c|c|c|}
\hline No. & $\begin{array}{l}\text { Type of } \\
\text { breeding }\end{array}$ & Head, ... & \begin{tabular}{|lr} 
Total net & net \\
income & in \\
Tomans &
\end{tabular} & $\begin{array}{l}\text { Household } \\
\text { share in } \\
\text { Tomans }\end{array}$ & $\begin{array}{l}\text { Job } \\
\text { creation } \\
\text { per person }\end{array}$ \\
\hline
\end{tabular}




\begin{tabular}{|l|l|l|l|l|l|}
\hline 1 & $\begin{array}{l}\text { Light livestock } \\
\text { (sheep) }\end{array}$ & 9761 & 4680000000 & 5880000 & 39 \\
\hline 2 & $\begin{array}{l}\text { Heavy } \\
\text { livestock } \\
\text { (cattle and } \\
\text { calves) }\end{array}$ & 184 & 552000000 & 670000 & 7 \\
\hline 3 & Camel & 1936 & 4840000000 & 6000000 & 28 \\
\hline Total & 11881 & 10072000000 & 12550000 & 74 \\
\hline
\end{tabular}

Source: Jihad Agricultural Organization of South Khorasan Province and the author's calculations

Table 5 provides information on comparing incomes and job creation in different economic sectors in the sample villages. According to the information in this table, the highest income is related to the agricultural sector and the lowest income is related to the industrial sector, the highest employment rate is related to the agricultural sector and the lowest employment rate is related to the service sector.

\section{Table 5}

\section{Comparison of income and job creation of different economic sectors in sample} villages

\begin{tabular}{|l|l|l|l|l|l|}
\hline No. & $\begin{array}{l}\text { Economic } \\
\text { sectors }\end{array}$ & $\begin{array}{l}\text { Total income } \\
\text { in Tomans }\end{array}$ & $\begin{array}{l}\text { Share of } \\
\text { each part of } \\
\text { total } \\
\text { revenue as } \\
\text { a } \\
\text { percentage }\end{array}$ & $\begin{array}{l}\text { Total } \\
\text { employment }\end{array}$ & $\begin{array}{l}\text { The share } \\
\text { of each } \\
\text { sector of } \\
\text { job } \\
\text { creation in } \\
\text { percentage }\end{array}$ \\
\hline 1 & Agriculture & 38101700000 & 97.7 & 149 & 46.4 \\
\hline 2 & Industry & 168000000 & 0.5 & 133 & 41.4 \\
\hline 3 & Services & 718200000 & 1.8 & 39 & 12.2 \\
\hline 4 & Total & 38987900000 & 100 & 321 & 100 \\
\hline
\end{tabular}




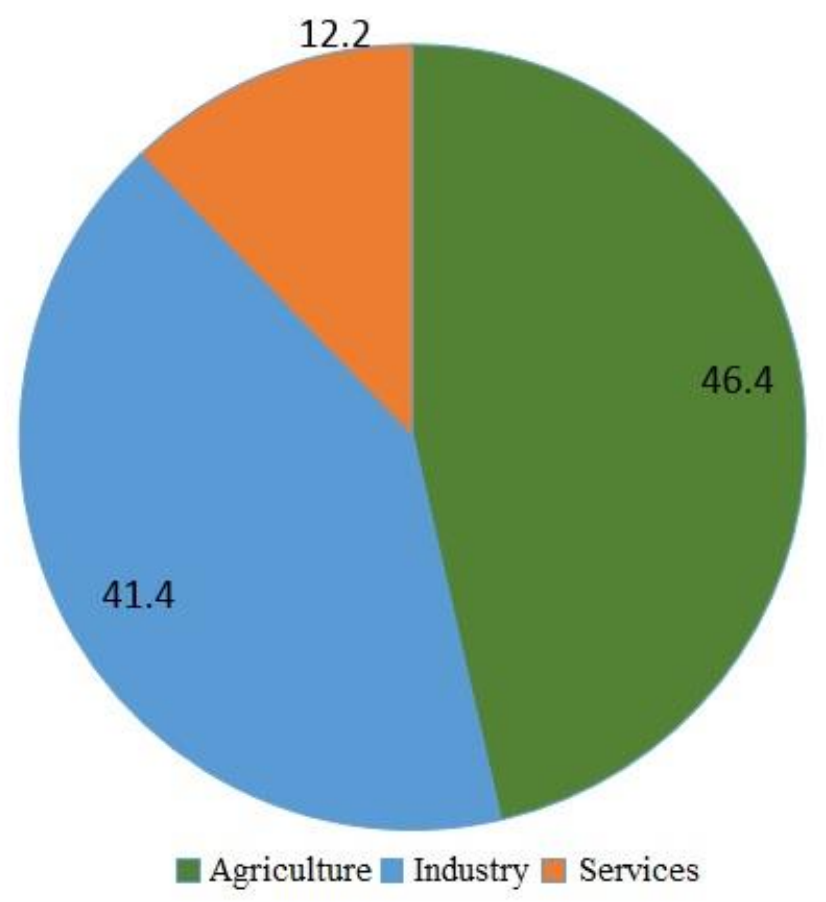

\section{Graph 1}

The share of each sector of job creation in percentage

\section{Table 6}

Frequency distribution of the effect of lack of facilities and services on population instability

\begin{tabular}{|l|l|l|}
\hline Items & Frequency & Percent \\
\hline very little & 1 & 0.6 \\
\hline Low & 7 & 2.9 \\
\hline Medium & 41 & 15.7 \\
\hline High & 75 & 28.8 \\
\hline Very High & 135 & 52 \\
\hline Total & 259 & 100 \\
\hline
\end{tabular}

According to the results of Table 6, the respondents stated that the impact of the lack of facilities and services needed on population instability was $52 \%$ very high, $28.8 \%$ high, $15.7 \%$ medium, $2.9 \%$ low and $0.6 \%$ very low. 


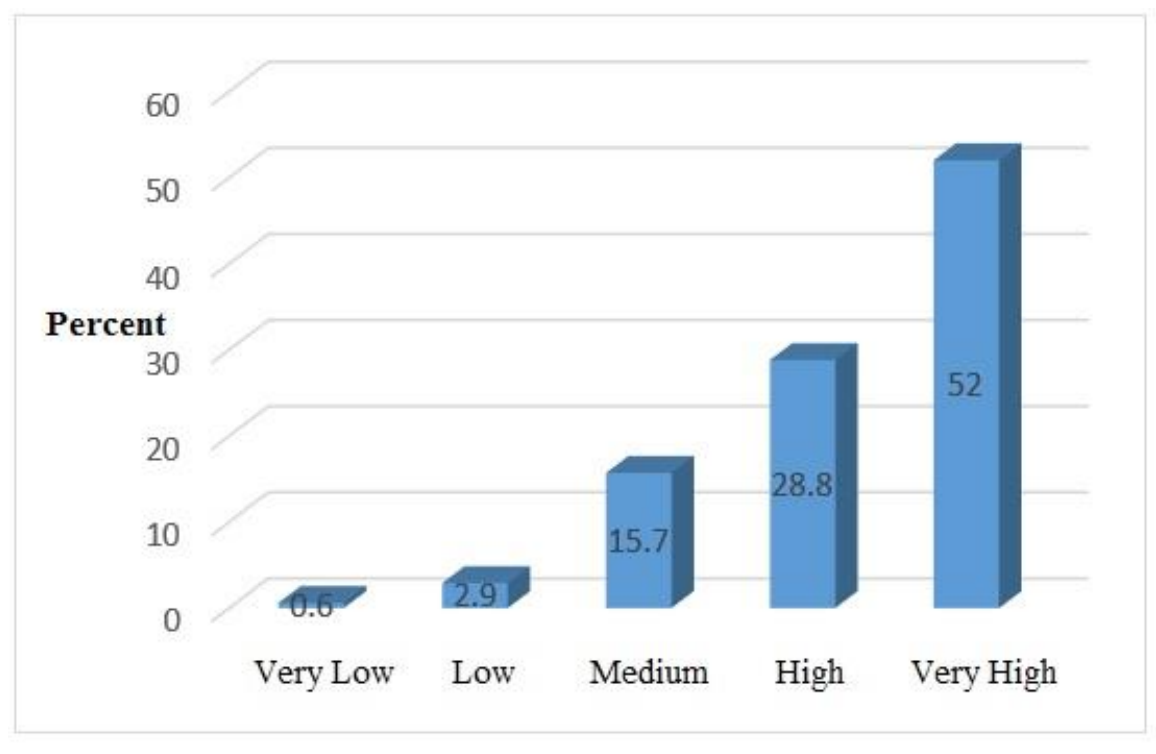

\section{Graph 2}

Frequency percentage of the impact of lack of facilities and services on population instability

Based on the results of the above table and chart, a total of $80.8 \%$ of respondents considered the impact of lack of facilities and services on population instability to be high and very high.

The Impact of Poverty on Population Instability

Table 7

Frequency distribution of the impact of poverty on population instability

\begin{tabular}{|l|l|l|}
\hline Items & Frequency & Percent \\
\hline very little & 7 & 2.7 \\
\hline Low & 7 & 2.7 \\
\hline Medium & 22 & 8.5 \\
\hline High & 75 & 28.8 \\
\hline Very High & 148 & 57.3 \\
\hline Total & 259 & 100 \\
\hline
\end{tabular}

According to the results of Table No. 5-17, the respondents expressed the effect of poverty on population instability as $57.3 \%$ very high, $28.8 \%$ high, $8.5 \%$ moderate, $2.7 \%$ low and $2.7 \%$ very low. 


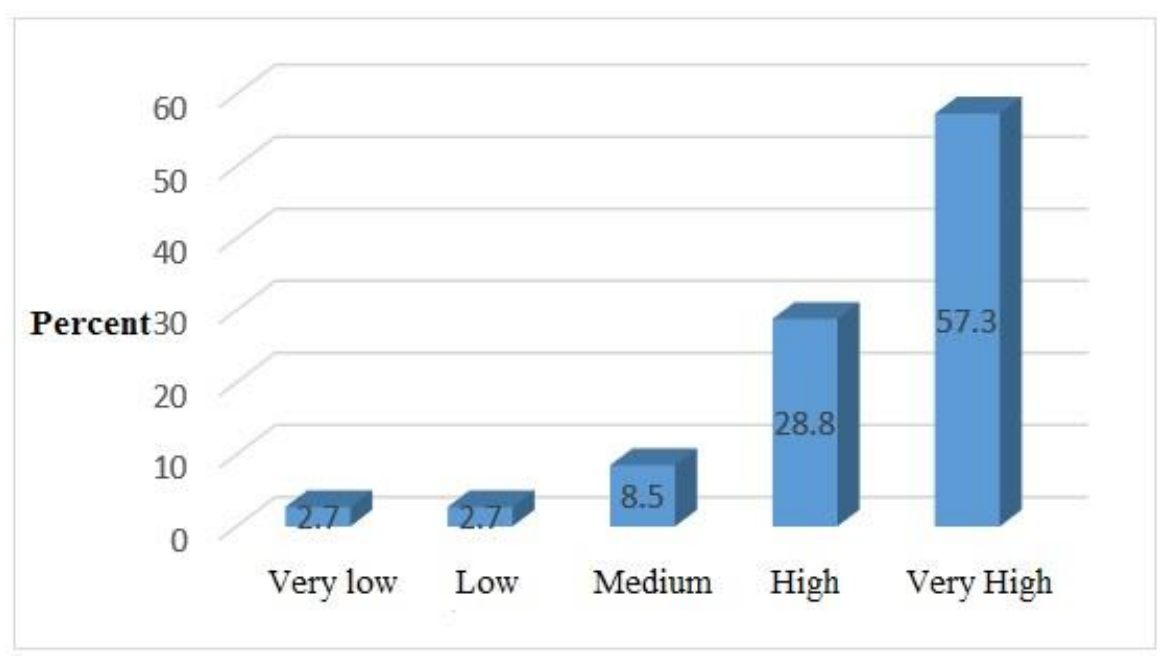

\section{Graph 3}

\section{Percentage of the impact of poverty on population instability}

Based on the results of the above table and chart, a total of $86.1 \%$ of respondents considered the impact of poverty on population instability to be high and very high.

The effect of rural economic situation on population instability

\section{Table 8}

Frequency distribution of the impact of rural economic situation on population instability

\begin{tabular}{|l|l|l|}
\hline Items & Frequency & Percent \\
\hline very little & 5 & 1.9 \\
\hline Low & 8 & 3.1 \\
\hline Medium & 25 & 9.7 \\
\hline High & 69 & 26.6 \\
\hline Very High & 152 & 58.7 \\
\hline Total & 259 & 100 \\
\hline
\end{tabular}

According to the results of Table No. 5-18, the respondents rate the impact of the economic situation of the village on the instability of the population as $58.7 \%$ very high, $26.6 \%$ high, $9.7 \%$ moderate, $3.1 \%$ low and $1.9 \%$ have expressed very little effect. 


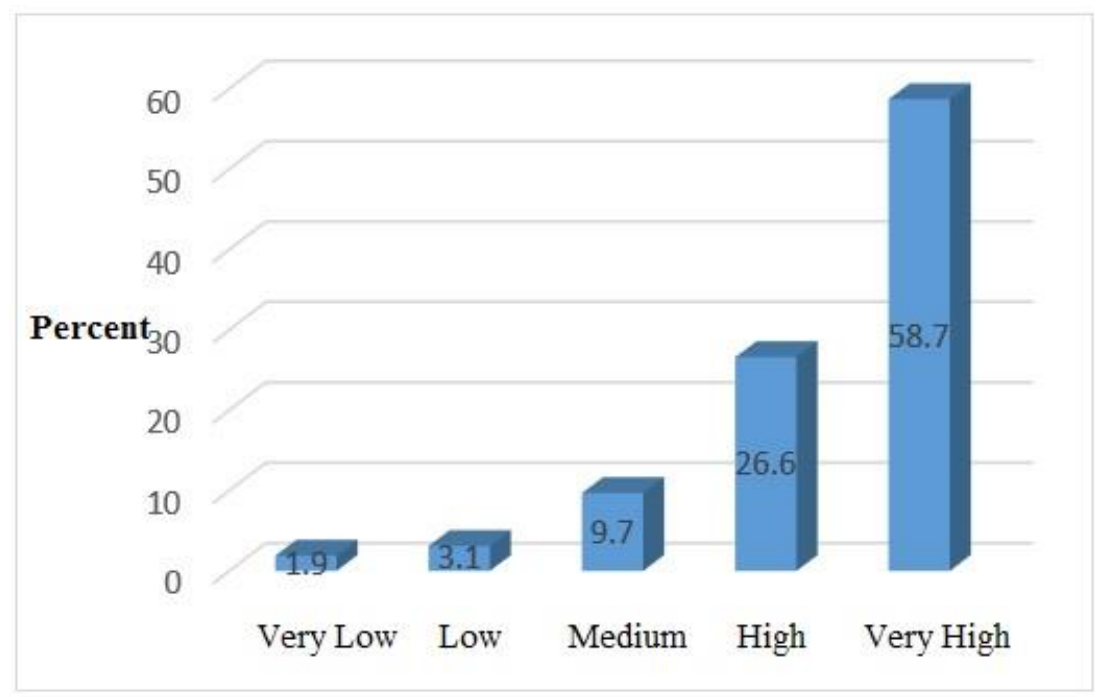

Figure 4

Frequency percentage of the impact of rural economic situation on population instability

Based on the results of the above table and chart, a total of $85.3 \%$ of respondents considered the impact of damage to the rural economy on population instability to be high and very high.

\section{Impact of low income on population instability}

Table 9

Frequency distribution of the effect of low income on population instability

\begin{tabular}{|l|l|l|}
\hline Items & Frequency & Percent \\
\hline very little & 2 & 0.6 \\
\hline Low & 6 & 2.3 \\
\hline Medium & 32 & 12.5 \\
\hline High & 90 & 34.8 \\
\hline Very High & 129 & 49.8 \\
\hline Total & 259 & 100 \\
\hline
\end{tabular}

According to the results of Table 5-22, the respondents stated that the impact of low income on population instability was $49.8 \%$ very high, $34.8 \%$ high, $12.5 \%$ medium, $2.3 \%$ low and $0.6 \%$ very low. 


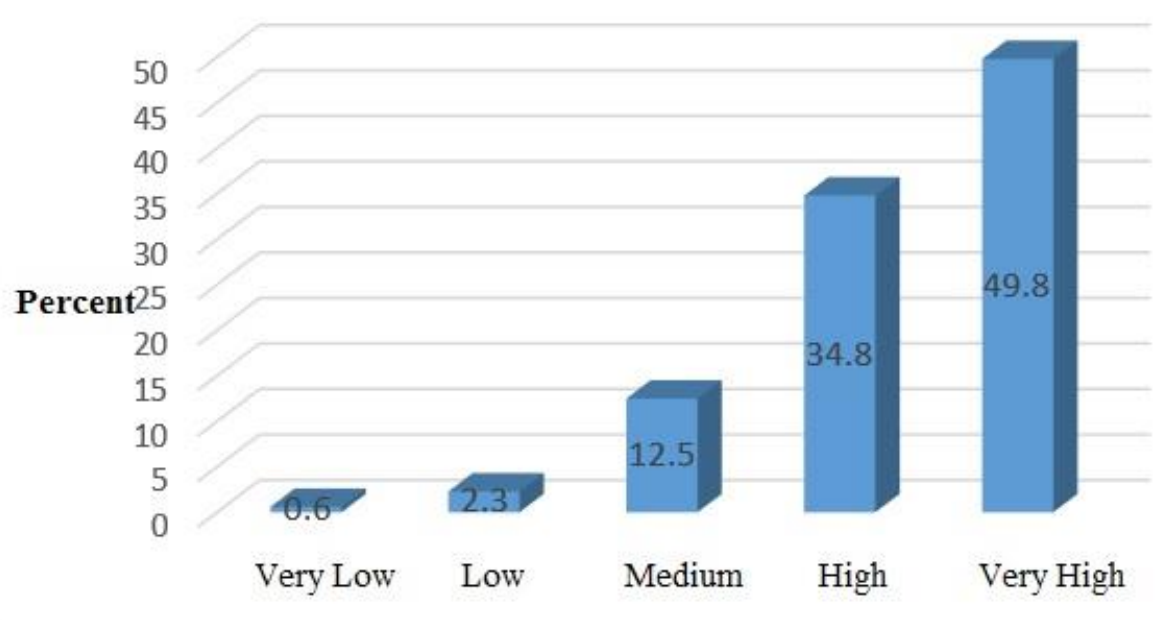

Figure 5

\section{Percentage of low-impact impact on population instability}

Based on the results of the above table and chart, a total of $84.6 \%$ of respondents considered the impact of low income on population instability to be high and very high.

\section{Impact of lack of jobs and non-agricultural work on population instability}

Table 10

Frequency distribution The effect of lack of jobs and non-agricultural work on population instability

\begin{tabular}{|l|l|l|}
\hline Items & Frequency & Percent \\
\hline very little & 4 & 1.5 \\
\hline Low & 8 & 3.2 \\
\hline Medium & 34 & 13.1 \\
\hline High & 93 & 35.8 \\
\hline Very High & 120 & 46.4 \\
\hline Total & 259 & 100 \\
\hline
\end{tabular}

According to the results of Table 10, the respondents found the effect of lack of nonagricultural jobs and work on the instability of the rural population as $46.4 \%$ very high, $35.8 \%$ high, $13.1 \%$ medium, $3.2 \%$ low and 1.5 The percentage is very low. 


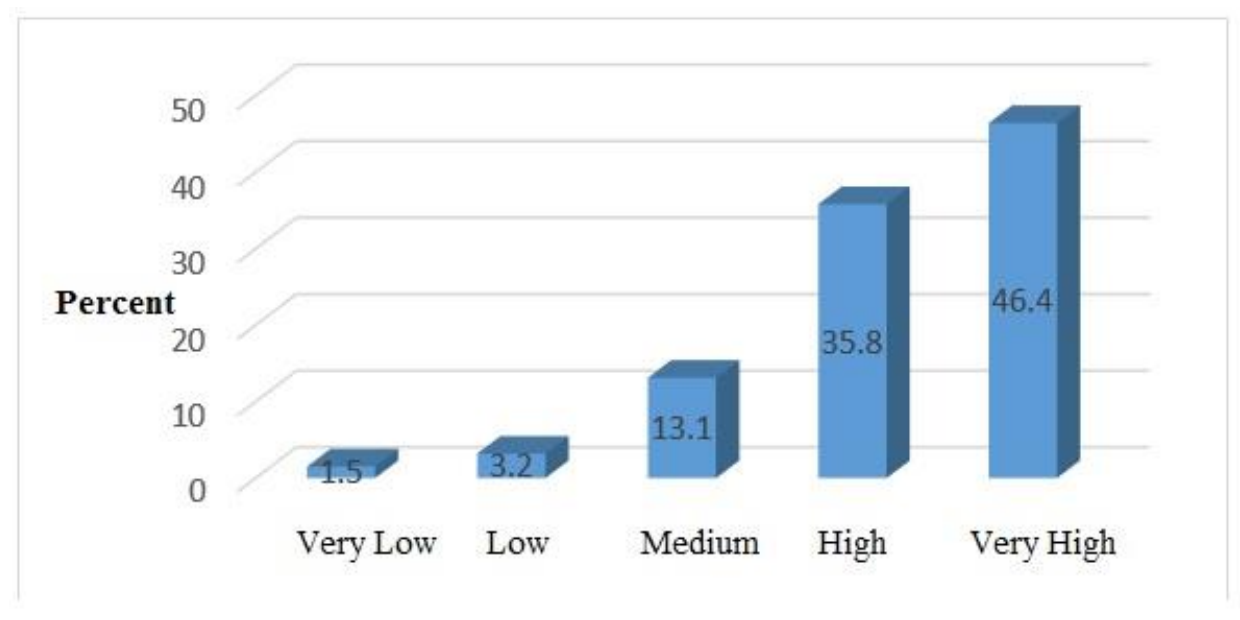

Figure 6

Frequency percentage of the lack of impact of non-agricultural jobs and work on population instability

Based on the results of the above table and chart, a total of $82.2 \%$ of respondents considered the lack of impact of non-agricultural jobs and work on population instability to be high and very high.

The effect of economic incentives on population instability

\section{Table 11}

Frequency distribution of the impact of economic incentives on population instability.

\begin{tabular}{|l|l|l|}
\hline Items & Frequency & Percent \\
\hline very little & 1 & 0.4 \\
\hline Low & 2 & 0.8 \\
\hline Medium & 11 & 4.2 \\
\hline High & 69 & 26.6 \\
\hline Very High & 176 & 68 \\
\hline Total & 259 & 100 \\
\hline
\end{tabular}

According to the results of Table 11, the respondents stated that the impact of economic factors in general on population instability was $68 \%$ very high, $26.6 \%$ high, $4.2 \%$ moderate, $0.8 \%$ low and $0.4 \%$ very low. 


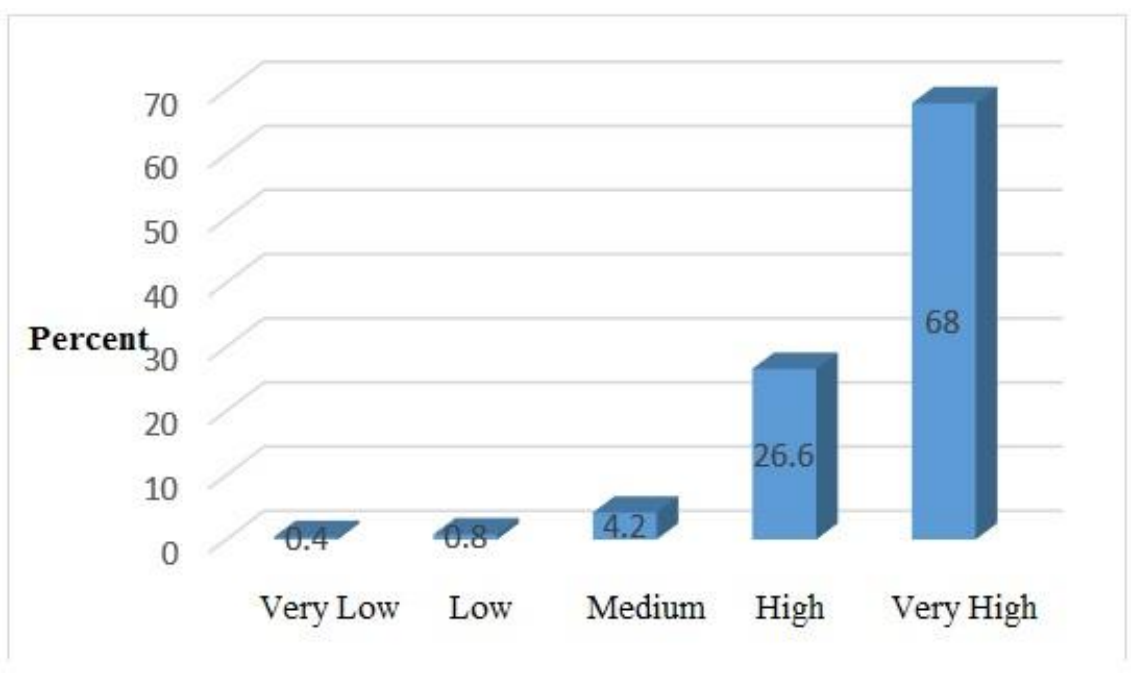

Figure 7

\section{Frequency of the impact of economic incentives on population instability}

Based on the results of the above table and chart, a total of $94.6 \%$ of respondents considered the impact of economic incentives on population instability to be high and very high.

\section{Conclusion}

There seems to be a significant relationship between economic factors (unemployment and low income) and population instability in the studied rural settlements. Based on the results of Table 12, for the variable of economic factors (unemployment and low income) and all its dimensions, the t-statistic is positive and the significance level is zero (which is less than 0.05). This indicates the average of all These variables are more than 3 and have a significant effect on population instability in rural settlements of Khoosf city, so the second hypothesis is confirmed.

Table 12

Results of one-sample t-test for economic factors (unemployment and low income) and its dimensions

\begin{tabular}{|l|l|l|l|l|}
\hline Variable & Average & t Statistic & $d f$ & Sig. Level \\
\hline finding a job & 4.44 & 37.13 & 341 & 0.000 \\
\hline Low income & 4.31 & 29.32 & 340 & 0.000 \\
\hline Low wages & 4.34 & 30.06 & 343 & 0.000 \\
\hline $\begin{array}{l}\text { Income } \\
\text { difference } \\
\text { between city } \\
\text { and village }\end{array}$ & 4.15 & 25.54 & 343 & 0.000 \\
\hline
\end{tabular}




\begin{tabular}{|l|l|l|l|l|}
\hline $\begin{array}{l}\text { Lack of non- } \\
\text { agricultural jobs } \\
\text { and work }\end{array}$ & 4.22 & 25.16 & 341 & 0.000 \\
\hline $\begin{array}{l}\text { Seasonal } \\
\text { unemployment }\end{array}$ & 3.94 & 17.57 & 341 & 0.000 \\
\hline $\begin{array}{l}\text { Total (Economic } \\
\text { incentives) }\end{array}$ & 4.31 & 43.12 & 343 & 0.000 \\
\hline
\end{tabular}

One of the most important issues for researchers and government officials in recent decades is the issue of population instability in rural settlements and its social, cultural, economic and security consequences. What seems important and necessary at the beginning is to identify the factors affecting the population instability of rural settlements and find solutions to reduce population instability and its negative effects and consequences. The present study showed that the main causes of population instability in rural areas of the region are economic factors (unemployment and low income) and lack of facilities and services. Considering that the most important source of income for the villagers is the agricultural sector, managers and planners in the rural area should prioritize the economic programs and policies of the agricultural sector and related activities, and on the other hand, through the diversification of the economy in rural areas contribute to population sustainability in rural areas.

There are several issues and problems such as:

- It takes time to receive answers to inquiries to create conversion and complementary industries, livestock farms and livestock complexes, etc., which cause great losses to farmers and ranchers and increase costs.

- Lack of sufficient capital by farmers and ranchers in the sample villages to invest and upgrade the tools and equipment used, as well as lack of collateral and credit to receive facilities in the agricultural sector.

Also, there are some solutions such as:

- Investing in renewable energy is another income-generating capacity in Khoosf city that can improve the living conditions of villagers on the one hand and increase the motivation to stay in rural areas on the other hand.

- The mining sector is one of the important capacities of Khoosf city that should be paid more attention. It is necessary to conduct systematic studies related to mineral exploration and extraction in Khoosf city in order to make the most of this God-given capacity.

- Paying cheap facilities to small industries, conversions and important products of the city can improve the living conditions of the people of the city and the survival of the population.

- Promoting and developing the carpet weaving industry and supporting weavers with incentive schemes, payment of cheap facilities and social security insurance can have a great impact on creating jobs for rural youth, especially women, reducing migration and increasing the survival of villagers.

- Due to the gold mines that exist in Khoosf city with high capacity, such as Shadan 
gold mine and GhalehZari, by setting up a gold processing factory in the city and using domestic and foreign investors in this field, many jobs can be created, which results in It increases the attraction of Khoosf city and reduces migration from villages.

- Considering that 86 historical monuments have been nationally registered in Khoosf city and there are villages targeted for tourism and natural protected areas, so one of the ways to increase the income of villagers and create employment and proportionally increase the survival of villagers is to pay special attention to the tourism industry. Holding local and indigenous festivals at the provincial and national levels can be effective in introducing tourist attractions.

\section{Reference}

Ali Abbasi Khiavi, S. (2017). Study and Analysis of Challenges and Strategies of Rural Migration, Fifth International Conference on New Ideas in Agriculture, Environment and Tourism, Iran, Tehran.

Bhaga, R. (2017). Migration and Urban Transition in India: Implications for Development, United Nations Expert Group Meeting On Sustainable Cities, Human Mobility And International Migration Population Division Department of Economic and Social Affairs United Nations Secretariat, New York $\mathrm{UN} / \mathrm{POP} / \mathrm{EGM} / 2017 / 3$

Bekan, M. (2015). Factors of instability of rural settlements, 3rd International Congress of Civil Engineering, Architecture and Urban Development, Shahid Beheshti University, Tehran.

Chukwuedozie, K., Ajaero, N., and Patience, C., \& Onokala, R. (2013). The Effects of Rural-Urban Migration on RuralCommunities of Southeastern Nigeria, Department of Geography, University of Nigeria, Nsukka.

Farmahini Farahani, B. (2015). Rural Development Projects and Rural to Urban Migration (Case Study: Carbon Sequestration Project). Scientific-Extension Quarterly of Science and Technology Policy, 5(3), 69-77.

Ismaili, F. (2017). The role of small industries in the social and economic development of rural areas (Case study: Gulab rural district of Kashan). Bimonthly Research in Arts and Humanities, 2, 12-32.

Jafarian, M. R., Yousefifar, S., \& Shabani, R. (2017). Quarterly Journal of Social History Research. Institute of Humanities and Cultural Studies, 7(2), 78-90.

Jangi, H. (2016). Evaluation of Factors Affecting Population Sustainability in Rural Settlements, Case Study: Chenaran Villages, $\mathrm{PhD}$ Thesis in Geography and Rural Planning, Department of Geography, Azad University of Mashhad, Supervisor: Hamid Jafari.

Janparvar, M., Salehabadi, R., \& Zargari, M. (2017). The Consequences of the Immigrant Crisis Due to Short-Term Droughts in Sistan and Baluchestan Province. Quarterly Journal of the Iranian Geographical Association, 15, 52-69.

K. Wegren, S. (2016). The Quest for Rural Sustainability in Russia; Southern Methodist University; Dallas, USA. 
Karimi Mohammad, H.M. (2016). Golden Techniques in Dissertation Writing: A Practical Guide to Dissertation Writing, First Edition, Library Publications.

Khatib, M.M. (2016). Planning and planning studies of the province (analysis of the post and heights of South Khorasan province), South Khorasan governorate.

Kiani, M. (2015). Demography of Iran, Second Edition, Payame Noor University Press.

Latifeh, N., Jahani, M., \& Jafari, H. (2016). Economic Factors Affecting the Instability of Rural Settlements, Case Study: Damavand Villages. Village and Development Quarterly, 19(1), 67-89.

Lucas, D., \& Mir, P. (2014). An Introduction to Social Studies, translated by Mahmoudian, Hossein, University of Tehran Press.

Mohammadi Yeganeh, B., \& Sanaei Moghadam, S. (2017). Analysis of the effects of urban and rural relations on rural-urban migration (Case study: Peshteh Zeilai village) Dehdasht city. Regional Planning Quarterly, 7, 27-45.

Mohammadi, S., Taleshi, M., \& Rostami, S. B. (2015). Instability of rural settlements from the perspective of councils and villages in the mountainous and foothills of the Zagros (Case study: villages of Marivan and Sarvabad counties). Journal of Geography (Scientific Quarterly) - International Research of the Geographical Society of Iran), 13, 46-56.

Mottaghi, S. (2015). The Impact of Economic Factors on Migration in Iran: Emphasis on Income and Unemployment Indices. Quarterly Journal of Strategic and Macro Policies, 3(11), 56-77.

Nadifar, M., Poursafavi, \& S. Ma. (2017). The Impact of Groundwater Reduction on Rural Migration (Case Study: Qazvin County), Islamic Azad University, Qazvin Branch, 4th National Conference on Architecture and Urban Planning (Sustainability, from Ideal to reality)

Nasiri Hind Khaleh, E. (2016). The Impact of Migration on Urban Development Using the SWOT Model, Case Study: Shahr-e Babol. Bi-Quarterly Journal of Urban Ecological Research, 7(2), 87-94.

Nikzad, M, \& Sedighian, H. (2015). New Evidence from the Paleolithic period in the city of Khosf, South Khorasan, northeastern margin of the Lut Desert in eastern Iran. Payam Archaeologist Magazine, 24, 56-67.

Rezaei, M. R. (2016). Planning and Planning Studies of South Khorasan Province (Environmental Analysis), South Khorasan Governorate.

Rokanuddin Eftekhari, A. (2018). Evaluation and Analysis of Rural Master Plan Articles in Iran. Rural Research Quarterly, 9(1), 12-30.

Saadi, H., Bahrami, L., \& Afshar Kohan, J. (2014). Causes of rural migration in Hamadan province (Malayer city, Jokar district). Journal of Social Sciences, Ferdowsi University of Mashhad, 11(1), 99-113.

Sarmad, Z., Bazargan, A., \& Hejazi, E. (2017). Research Methods in Behavioral 
Sciences, Tehran, Agha Publications.

Soleimani, M., \& Bouzarjomehri, K. (2014). "Population Sustainability of Rural Settlements in Arid and Semi-Arid Areas, Case Study: Sarayan County". South Khorasan Law Enforcement Quarterly, 3(4), 34-50.

Tamnna, S. (2014). Fundamentals of Demography, Twelfth Edition, Payame Noor University Press.

Zahedi, S. S. (2013). Sustainable Development, seventh edition, Samat Publications. 